\title{
Cumulative effects of risperidone long acting injection and narrative therapy in treating ethanol dependency
}

\author{
Maria Silvia Trandafir \\ From $1^{\text {st }}$ International Congress on Neurobiology and Clinical Psychopharmacology \\ and European Psychiatric Association Conference on Treatment Guidance \\ Thessaloniki, Greece. 19-22 November 2009
}

\section{Background}

Aims/objectives: Rationale: Ethanol dependency is among the most frequent psychiatric disorders regardless of age and sex and currently affecting an increasing number of women and children. Its treatment stands on the clinician's decision, family and/or social group support. Our aim is to assess the efficacy of using risperidone long-acting injection along with psychotherapy in gamma type alcohol dependency.

\section{Materials and methods}

Method: Case study. Gathering self-reported data, psychotherapy sessions for the patient and his/her family, data analysis.

For relevance purposes we shall present below the case of a 30 yo Caucasian male with a history of alcohol consumption since he was 12 yo. During the past year his alcohol consumption started to follow a daily pattern. The patient's psychopathological presentation is dominated by psychomotor agitation, hypnic disorders, hetero-aggression, interpretative thoughts, depressive ideation, low self-esteem, social, professional and family desinsertion. Following the first four hospital admissions during which he received thymoregulatory, antidepressive and sedative agents his alcohol consumption increased and symptomatology intensified. During his fifth hospital admission the patient received risperidone $2 \mathrm{mg}$ per day, as a neuroleptic agent, followed by risperidone long-acting injection $25 \mathrm{mg}$ once every 2 weeks. After hospital discharge his condition improved incrementally. Two months after hospital release he relapses for two days but is able to cease consumption without

Alexandru Obregia Hospital, Unit 7, Bucharest, Romania external help. The patient is currently professionally and socially active and his family interactions are healthy. Along with risperidone long-acting injection therapy he was admitted to family therapy sessions every week during the first two months, every two weeks for the next two months followed by a monthly session during the next 6 months.

\section{Conclusions}

Using risperidone long-acting injections along with narrative therapy has protracted the abstinence period and has also contributed to social and family reinsertion.

Published: 22 April 2010

\section{References}

1. White Michael: Maps of Narrative practice. Norton Professional Books 2007. 2. Morgan Alice: What is Narrative Therapy, Gecko 2002.

doi:10.1186/1744-859X-9-S1-S157

Cite this article as: Trandafir: Cumulative effects of risperidone long acting injection and narrative therapy in treating ethanol dependency. Annals of General Psychiatry 2010 9(Suppl 1):S157.

Submit your next manuscript to BioMed Central and take full advantage of:

- Convenient online submission

- Thorough peer review

- No space constraints or color figure charges

- Immediate publication on acceptance

- Inclusion in PubMed, CAS, Scopus and Google Scholar

- Research which is freely available for redistribution

Submit your manuscript at www.biomedcentral.com/submit 